\title{
Oyirad Terms for the Manchus
}

HOSUNG SHIM

Indiana University Bloomington

Volume 15, 2018

This article examines how the Oyirads denominated the Manchus and what the Oyirad terms for the Manchus meant. The Oyirads employed both "China" and "Manchu" to denote the Manchus and their empire. Before the Manchus conquered China, the Oyirads identified them and their state simply as the Jurchens and the Jin. After the Manchus successfully occupied Beijing and China proper, the Oyirads began to refer to a Manchu emperor as the khan of China who took over the state of Dayiming. As opposed to the Manchus, who considered the ethnic label "Chinese" pejorative, the Oyirads did not mean to denigrate the Manchus with the new nomenclature. Instead, by calling them Chinese, the Oyirads acknowledged the great achievement of the Manchu rulers and recognized their elevated title and political status. In other words, it was a significant promotion of the Manchus that the Oyirads altered the title of their ruler from khan of the Jurchens to khan of China. Since then, the Oyirads continued to call the Qing Empire and the Manchu court "China" or "Chinese." By the early eighteenth century, however, the ethnonym Manchu entered Zungharia. Although usage of this new word grew among the Oyirads over time, the Oyirads never abandoned their custom of referring to the Qing and the Manchus as China or Chinese. Therefore, in later Oyirad writings, the terms China and Manchu were used simultaneously.

卫拉特蒙古对满洲的称谓问题

Hosung Shim 沈昊成

印第安纳大学伯明顿分校

摘要

本文着重考察了卫拉特蒙古对满洲的不同称呼以及称呼背后的含义。卫拉特 蒙古使用“kitad(中国)”和“manju(满洲)”这两种称谓指代满人和他们的帝国。 在满人征服中国前, 卫拉特蒙古仅仅将满人视为女真, 满人的国家视为金 国; 而满人入关成功占据北京并南下征服中国之后, 卫拉特蒙古开始将满洲 皇帝称为“取得了明朝的政权的中国可汗”。与将“nikan/kitad”这满蒙单词视 作贬义的满人不同, 卫拉特蒙古并非借此称呼贬低满人, 恰恰相反, 将满人 
和清朝称为中国的是卫拉特蒙古对于满洲统治者的功业成就和政治地位的认 可，即满洲统治者从女真可汗变成了中国可汗，这是一种巨大的地位提升。 此后, 卫拉特蒙古一直称满人和他们的帝国为中国人和中国。虽然十八世纪 早期, “满洲”这一称呼进入了准噶尔并被越来越多地使用, 卫拉特蒙古依然 习惯性地指代满清为中国。因此, 在更晚期的一些文本中, 我们仍可以看到 中国和满洲两个称呼的交替使用。

衛拉特蒙古對滿洲的稱謂問題

Hosung Shim 沈昊成

印第安納大學伯明頓分校

摘要

本文著重考察了衛拉特蒙古對滿洲的不同稱呼以及稱呼背後的含義。衛拉特 蒙古使用“kitad(中國)”和“manju(滿洲)”這兩種稱謂指代滿人和他們的帝國。 在滿人征服中國前, 衛拉特蒙古僅僅將滿人視為女真, 滿人的國家視為金 國; 而滿人入關成功占據北京並南下征服中國之後, 衛拉特蒙古開始將滿洲 皇帝稱為“取得了明朝的政權的中國可汗”。與將“nikan/kitad”這滿蒙單詞視 作貶義的滿人不同, 衛拉特蒙古並非借此稱呼貶低滿人, 恰恰相反, 將滿人 和清朝稱為中國的是衛拉特蒙古對於滿洲統治者的功業成就和政治地位的認 可，即滿洲統治者從女真可汗變成了中國可汗，這是一種巨大的地位提升。 此後, 衛拉特蒙古一直稱滿人和他們的帝國為中國人和中國。雖然十八世紀 早期, “滿洲”這一稱呼進入了準噶爾並被越來越多地使用, 衛拉特蒙古依然 習慣性地指代滿清為中國。因此, 在更晚期的一些文本中, 我們仍可以看到 中國和滿洲兩個稱呼的交替使用。

\section{Introduction}

In Dayi juemi lu 大義覺迷錄, the Yongzheng emperor made a mysterious statement concerning the way that the Zunghars termed the Manchus. It reads

Moreover, all the Manchus would feel ashamed to be appended to the ranks of the Han Chinese. The Zunghars call the Manchus “Manzi 蠻子.” All the Manchus who hear this get furious and resent this. ${ }^{1}$

This passage clearly states that during the Yongzheng reign, the Zunghars infuriated the Manchus by denominating them "Manzi." From the context, it is manifest that the Manchus were offended by the term Manzi because they considered the appellation to

1. Dayi juemi lu (Taibei: Wenhai chubanshe, 1966), 1:43r (p. 85). 
designate Han Chinese. Here, two interesting questions arise. Did the Zunghars really deem the Manchus to be Chinese? What did they mean by using the term Manzi?

To answer these questions, it is necessary to delve into Zunghar terms for the Manchus and the Qing Empire. To unveil the Zunghar perspective on the Manchus and the Qing, it is crucial to investigate various Oyirad language sources written in the Clear Script (i.e., todorxoi üjüq, or todo bichig). ${ }^{2}$ Unfortunately, there is no surviving Oyirad Clear Script source composed by the Zunghars themselves during the seventeenth and eighteenth centuries, except for a few remaining pieces of diplomatic correspondence. Therefore, this research will consult not only the Oyirad language chronicles written by other groups of Oyirad peoples, such as the Khoshuuds, the Torghuuds, and the Dörböds, but also several Clear Script diplomatic letters written by the Zunghars and now preserved in the Qing archives.

\section{Evidence from The Biography of Zaya Pandita}

One of the earliest known historical sources written in the Clear Script is The Biography of Zaya Pandita (composed probably in 1691 by Radnaabadraa, a disciple of Zaya Pandita). ${ }^{3}$ This biography provides several interesting passages concerning the Manchu court and the Qing Empire.

[1] At that time [in the spring of 1647], Targhun Erdeni Khung-tayiji decided to go to Tibet (baroun tala). [To this end,] he himself gathered many animals and sent the units of his livestock to China (kitadtu). Moreover, he offered six thousand sheep to Zaya Pandita. ${ }^{4}$

2. Radnaabadraa, Rawjam zaya bandidyn tuuj sarny gerel khemeekh orshiw, ed. Kh. Byambajaw (Ulaanbaatar: Tod nomyn gerel töw and Soyombo printing, 2009), 96:8r (hereafter Biography of Zaya Pandita).

3. According to The Biography of Zaya Pandita, before becoming a monk, Zaya Pandita originally belonged to the Khoshuud group of the Oyirads. After finishing his religious degree in Tibet, he came back to the land of the Oyirads to propagate Buddhism. Even though he was widely revered both by the Khalkha Mongols and by all the groups of the Oyirads, his chief patron was Ochirtu Tayiji (later enthroned as Ochir Tsetsen Khan in 1666) of the Khoshuud. Moreover, Zaya Pandita's order fell into an uneasy relationship with the Zunghar ruling elites especially after Galdan of the Zunghar defeated and then replaced Ochir Tsetsen Khan as the leader of all Oyirads in Central Asia. Therefore, it is reasonable to see that The Biography of Zaya Pandita is not a historical source composed by a Zunghar author. This biography, however, is still a critical historical source to understand the Zunghar viewpoint on the Qing and the Manchus. First of all, the Zunghars were an integral part of the Oyirad Confederation known as the Four Oyirads (dörbön oyirad). Furthermore, most of the Oyirad groups once under the leadership of Ochir Tsetsen Khan acknowledged Galdan of the Zunghar as their supreme ruler after the downfall of Ochir Tsetsen Khan, as did the disciples of Zaya Pandita. Therefore, it is cogent that the author of the biography shared a general worldview with the Zunghars.

4. Biography of Zaya Pandita, $95: 7 \mathrm{v}$.

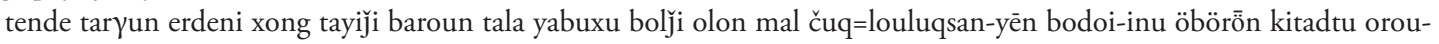

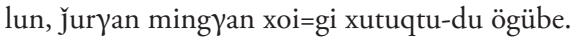


[2] At that time [in the summer of 1647], [Tsetsen Khan] went back to his pavilion and then convened jayisangs and demüchis of every otog. [Then, he] said: "I intend to go to Tibet (baroun tala)! I will assemble ten thousand geldings and send [them] to China (kitadtu)!" After that, he gathered ten thousand geldings and dispatched one hundred people [to China] with Khonjin Lama of the Mongols as their head. ${ }^{5}$

[3] At that time [in the autumn of 1650], [Zaya Pandita] came, without delay, quickly to [Tsetsen] Khan's pavilion which was then in [a place called] Küürgeyin Khōl. At that time, traders of ten thousand geldings came back from China (kitad-ēere). ${ }^{6}$

[4] In the winter of that year of the dog (1658), [Zaya Pandita] wintered in [a place called] Shara Tokhoi. In the autumn of the [same] year, Chagzodba Tsorji came from China (kitadāsa). ${ }^{7}$

What does China (kitad) mean in these passages? In this regard, Qing sources offer several interesting clues. First, according to The Veritable Records of the Qing Dynasty, it seems that an envoy named Ubashi 吳巴什 sent by Erdeni 額爾德尼 arrived in Beijing by November 3, 1647 (Shunzhi 4/10/7). ${ }^{8}$ It is highly probable that this Erdeni is the same person as Targhun Erdeni Khung-tayiji in the first quotation. "Targhun" should be an epithet of this person, meaning fat, and "Khung-tayiji" is unquestionably a title given to him. ${ }^{9}$ Therefore, it is plausible that the real name of Targhun Erdeni Khung-

5. Biography of Zaya Pandita, 96:8r-97:8v.

tende örgü=dōn xarīd, otoq otogiyin jayisang demüči-noүoudi iröülēd, bi baroun tala odsu geji sananayibi. tümen aqta

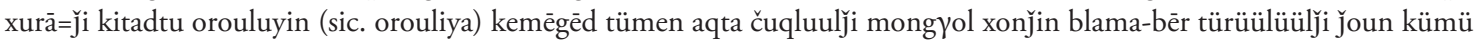
oroulbai.

6. Biography of Zaya Pandita, 97:8v.

tende tüdel-ügei ötör ireji xāni ör=gő küürgeyin xōldu bayixu-du kürči ireqsen-dü, tende ki=tad-ēče tümen aqtayin xudal-du ču kürči irebei.

7. Biography of Zaya Pandita, 119:19v.

tere no=xoi ǰiliyin übül šara toxoi-du übülǰebei. namur-inu pyaqmǰod pa čorǰi kitadāsa irebei.

8. Qing shilu 淸實錄 (hereafter Veritable Records; Beijing: Zhonghua shuju, 1985-1987), vol. 34, Shunzhi 4/10/7 (甲戌): “甲 戌, 上御太和殿, 賜厄魯特部落貢使額爾德尼吳巴仕等宴." This passage is literally translated as follows: “On the jiaxu day, the emperor proceeded to the Hall of Supreme Harmony and bestowed a feast on Erdeni Ubashi and others who were the tribute envoys of the Ület."

In this literal translation, however, it is unclear who Erdeni Ubashi would be. It could be the name of one person (i.e., Erdeni Ubashi) or the names of two people (i.e., Erdeni and Ubashi). Unfortunately, the translation does not explain anything about the Oyirad tribute mission and, moreover, is not adequate because the Veritable Records usually designate who (in most cases, nobilities or high lamas of the Mongols and the Oyirads at the time) sent envoys to the Qing court when recording tribute missions. Therefore, the passage should be translated differently for a better understanding. To be specific, the Chinese phrase “額爾德尼吳巴什” could also be translated as “Erdeni”s Ubashi” or “Ubashi of Erdeni.” In this revised translation, the meaning of the passage becomes much clearer: "the emperor . . . bestowed a feast on Erdeni's Ubashi, the tribute envoy of the Ület, and others." That is to say, the whole Oyirad tribute mission was headed by an envoy named Ubashi who belonged to Erdeni. In sum, an Oyirad noble called Erdeni sent his tribute mission to the Qing court with Ubashi as head in 1647.

9. According to the Xiyu tongwen zhi 西域同文志, Targhun Erdeni Khung-tayiji was the sixth son of Zasag Toyin, a younger brother of Bayibaghas and Güüshi of the Khoshuud. For details, see Qinding Xiyu tongwen zhi 欽定西域同文志 Hesei 
tayiji was simply Erdeni. According to The Biography of Zaya Pandita, this Erdeni sent his large units of livestock to China in the spring of 1647, and the Veritable Records stated that Erdeni's tribute envoy named Ubashi arrived in Beijing by November 1647. Therefore, it is convincing that China (kitad) means the Qing Empire in the first excerpt above.

According to the second quotation, Tsetsen Khan (i.e., Ochirtu Tayiji at the time) sent ten thousand geldings and one hundred people to China in the summer of 1647. A couple of Qing sources clarified that Ochirtu Tayiji's tribute mission arrived in Beijing by December 16, 1647 (Shunzhi 4/11/21). The Veritable Records stated that Ochirtu Tayiji of the Ület (厄魯特部落鄂濟爾圖台吉) offered horses as tribute, and a Mongolian document of the Inner Secretariat of the Qing Empire (i.e., Čing ulus-un dotuүadu narin bičig-ün yamun or Qing neimishuyuan 清内秘書院) testified that Ochirtu Tayiji of the Ögeled (ögeled wčir-tu tayiji) sent a document along with fifty horses as a gift. ${ }^{10}$ Therefore, it is probable that the envoys Ochirtu Tayiji sent to China with a large number of geldings in the summer of 1647 arrived at the Qing court by December of the same year.

The third excerpt indicates that in the autumn of 1650, traders of ten thousand geldings came back from China to Tsetsen Khan's pavilion in Küürgeyin Khōl. Again, Qing sources confirmed the arrival of Ochirtu Tayiji's tribute mission in Beijing in the summer of 1650. According to the Veritable Records, Ochirtu Tayiji of the Ület, Sonam of the Khalkha, and others (厄魯特部落鄂齊爾圖台吉, 喀爾喀部落索那穆 等) presented horses and other things as tribute on May 12, 1650 (Shunzhi 7/4/12). ${ }^{11}$ Furthermore, two Mongolian documents of the Inner Secretariat revealed that Ochirtu Tayiji (wčir-tu tayiǰi) presented documents and gifts to both the Shunzhi emperor ( $q a-$ muy-un ejen yeke qayan) and the Regent Dorgon (ama wang) on May 22, 1650 (Shunzhi 7/4/22)..$^{12}$ Thus, the traders who came back from China to Tsetsen Khan's pavilion in the autumn of 1650 should be Ochirtu Tayiji's tribute mission that arrived at the Qing court in Beijing in May 1650.

toktobuha wargi aiman i hergen be emu obuha ejetun i bithe (abbreviated XTZ; Tokyo: Toyo Bunko, 1964), vol. 4, table III, "Khoshot."

10. Dumdadu ulus-un nigedüger teüke-yin dangsa ebkemel-ün sang, Öbür mongүol-un öbertegen jasaqu orun-u dangsa

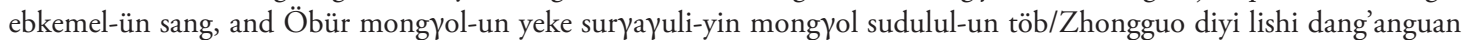
中国第一历史档案馆, Neimenggu zizhiqu dang'anguan 内蒙古自治区档案馆, and Neimenggu daxue Mengguxue yanjiu zhongxin 内蒙古大学蒙古学研究中心, eds., Čing ulus-un dotuyadu narin bičig-ün yamun-u mongyol dangsa ebkemel-ün emkidkel (Qing neimishuyuan Mengguwen dang'an huibian 清内秘书院蒙古文档案汇编; abbreviated CDME; Köke-qota: Öbür mong $\gamma$ ol-un arad-un keblel-ün qoriy-a, Huhehaote: Neimenggu renmin chubanshe, 2003), 2: 364-65, no. 49; Veritable Records, vol. 35, Shunzhi 4/11/21 (丁巳).

11. Veritable Records, vol. 48, Shunzhi 7/4/12 (乙未).

12. $C D M E$, 3: 117-19, nos. 8-9. Although there is a disagreement in the dates (i.e., Shunzhi $7 / 4 / 12$ vs. Shunzhi 7/4/22), this record in CDME should be identical with that in the Veritable Records under Shunzhi 7/4/12 (乙未). First, there is no passage at the date Shunzhi 7/4/22 in the Veritable Records. Moreover, according to the Mongolian document in CDME, Ochirtu Tayiji presented the Shunzhi emperor with three hundred horses in addition to other things (e.g., one vulture, one black fox, and one white fox), as recorded in the Veritable Records. 
Lastly, the fourth passage above shows that a high lama named Chagzodba Tsorji came from China to the land of the Oyirads in the autumn of 1658. According to the Veritable Records, Rabjamba Khutugtu and Changzodba Darkhan Tsorji of the Ület ( 厄魯特部落喇木占霸胡土克圖, 單信特霸達爾漢綽爾濟) arrived at the Qing court along with two other Khalkha envoys by December 16, 1647 (Shunzhi 4/11/21). ${ }^{13}$ Therefore, it is possible to see that Changzodba Tsorji came back to the land of the Oyirads in 1658 after his long stay in the Qing Empire. To sum up, throughout The Biography of Zaya Pandita, the term China (kitad) designates the Qing Empire or, more specifically, the Manchu court in Beijing. ${ }^{14}$

\section{Evidence from The History of the Four Oyirads}

The second source to consider is Emchi Ghabang Sharab's The History of the Four Oyirads (Dörbön Oyirodiyin Tö̈̈ke; composed in 1737 by Ghabang Sharab, a Torghuud literatus). This work also provides several interesting cues regarding the Oyirad view of the Manchus and the Qing.

13. Veritable Records, vol. 35, Shunzhi 4/11/21 (丁巳).

14. As discussed in this chapter, The Biography of Zaya Pandita employed the word China (kitad) to refer to the Qing Empire and the Manchu court in most cases. In the biography, however, there are two other interesting cases worth considering in terms of Oyirad nomenclature for the Manchus. In the first case, the author of the biography utilized the ethnonym "Jurchens" ( jürčid) to denote the Manchu emperor (Biography of Zaya Pandita, 109:14v). Although the meaning of this term is absolutely clear, it is likely that the ethnonym had an interesting connotation in the biography considering the context. The fourth section of this article will discuss it in detail.

On the second occasion, Radnaabadraa directly quoted a letter from the Dalai Lama sent to Zaya Pandita's disciples. In the missive, two ambiguous terms appeared: "dayibung xān” and "altan xān” (Biography of Zaya Pandita, 159:39v-160:40r). The meaning of these two titles is so obscure that numerous scholars have put forward a variety of explanations, especially regarding the term “dayibung xān.” For instance, Cheng Chongde 成崇德 translated this dayibung xān as “khan of peace and tranquility" (taiping khan 太平汗) without further explanation. Si. Norbu took dayibung xān as Toghon Temür, the last great khan of the Mongol Empire, after arguing that this dayibung xān should be someone other than the emperors of the Qing and the Ming Dynasties (i.e., Kangxi and probably Wanli respectively). Sazykin also understood dayibung xān as "taiping khan" but added a note that this dayibung/taiping khan signified the Kangxi emperor of the Qing Dynasty. Lastly, Kh. Byambajaw considered dayibung xān to be the Shunzhi emperor of the Qing. For details, see Cheng Chongde, trans., “Zaya bandida zhuan” 咱雅班第达传, in Qingdai Menggu gaosengzhuan yiji: Zhongguo bianjiang shidi ziliao congkan Menggu juan 清代蒙古高僧传译辑: 中国边疆史地资料丛刊 蒙古卷, ed. Zhongguo shehui kexueyuan Zhongguo bianjiang shidi yanjiu zhongxin 中国社会科学院 中国边疆史地研究中心 (Beijing: Quanguo tushuguan wenxian suowei fuzhi zhongxin, 1990), 52; Radnabhadra, Zay-a bandida, ed. Si. Norbu (Köke-qota: Öbür mong $\gamma o l-u n$ arad-un keblel-ün qoriy-a, 1999), 291n2; Radnabkhadra, Lunny̆ svet: Istoriia rabdzham Zaia-pandity, trans. G. H. Rumiantseva and A. G. Sazykina (Saint Petersburg: Peterburgskoe Vostokovedenie, 1999), 116n111; Biography of Zaya Pandita, 71n227.

In light of current scholarship on The Biography of Zaya Pandita, it is impossible to draw a definite conclusion concerning the two terms. To make an educated guess, however, it seems likely that dayibung xān possibly meant the Wanli emperor of the Ming, Altan Khan of the Tümed, or the Shunzhi emperor of the Qing, while the term altan xān might have signified Altan Khan of the Tümed or the Shunzhi emperor. To fully understand this obscure section of The Biography of Zaya Pandita, more thorough philological research will be required. Such philological examination of the biography, however, is far beyond the scope of this article. After all, a meticulous investigation of the two titles dayibung xān and altan xān, even if they did refer to the Qing emperor, would not be conducive for understanding the Oyirad nomenclature for the Manchus, because the two terms were originally found in the Dalai Lama's letter. 
[1] [The word of] Tsetsen Khan: "when I examine the Four Oyirads, the Barghus and Buriyads are going to become Russians (oros). The Khoyids are going to become Turkestanis (xoton). My brothers are going to become Tibetans and Chinese (töböd kitad). Moreover, the near Zunghars of mine are going to plunder me. It is not known whether the Zunghars are going to become Chinese (kitad) or Turkestanis (xoton)." 15

[2] The word of Dalai Khun-tayiji: "After encamping on [our] father's warm damp place (ötöq), we are going to become the number of someone else. After I die, it is a pity, my land (nutuq)!" By saying so, [he] reinforced the truth that [his people] became Chinese (kitad). ${ }^{16}$

[3] In Tibet, six great armies appeared, and when it was impossible to subdue and remove obstacles in the religion of the Buddha, [the six great armies] undertook to suppress and get rid of three great khans [in Tibet]. Beginning with his own very famous sons and nephews, it was Güüshi Khan, having good and great merits, the protector of the religion of the Buddha, that shook Ü-Tsang (üüzang), K'aras [i.e., Khara-usu? Kham?], Mg'omok'o [i.e., Mgo-log?], Dam, Amdo (anduu), the Four Foreigners and Five Colors (dörbön xari tabun önggü), China (kitad), Mongol, and Oyirad. ${ }^{17}$

[4] Dalai Tayishi of the Dörböd lost [his own land] by letting his wife rule [it]. Some people say that [he] lost it because he killed his son Manjou (küböügèn manjongi). Some people [say that he] lost it by disease. ${ }^{18}$

In the first excerpt, Ghabang Sharab depicted the political situations of the Four Oyirads of his time through the mouth of Ochir Tsetsen Khan of the Khoshuud. In other words, when Ghabang Sharab wrote this passage in 1737, it was widely perceived that the Barghus and Buriyads had already become part of the Russian Empire; the Khoyids had become almost assimilated to the sedentary people in Alti-shahr; the Khoshuuds settled in Tibet and Qinghai had become Tibetans and Chinese; the Zunghars had

15. Ghabang Sharab, "Gharban sharawyn zokhioson tod üsgiĭn dörwön oĭradyn tüükh” (abbreviated DOT), National Library of Mongolia, Ms. no. 1407/96, ff. 10-11.

čečen xān[,] dörbön oyirodi šinjileküdü mini. barүu burād oros bolxu. xoyid xoton bolxu. mini axa döü töböd kitad bolxu. mün namayigi oyiroki jö̈̈n $\gamma$ ar mini idekü. jö̈̈n yar kitad bolum[,] xoton bolum ülü medeqdenei.

16. DOT, f. 12 .

dalai xun tayiǰiyin ǰarliq[,] ečigeyin xaloun ötöqtu buuүād[,] kümüni tō bolnoi bida. namai üküqsen xoyino xayiran nutuq mini keqsēr, kitad boluqsan ünen kücüüldeqsen bui.

17. DOT, f. 8.

töbödtu juryān yeke čereq bolǰi; burxani šaǰin-du ǰedker daruǰi, ügei ese čidaqsan, čaqtu[,] ekelen $\gamma u r b a n$ yeke xāni daruji ügei bolyoqson. üüzang k’aras mg'omok'o dam anduu, dörbön xari tabun önggü, kitad mongyol oyirod dorgiloqsan[,] yeke neretei öböriyin küböün ǰēner ekilen burxani šajini bariqči sayin yeke ačitai güüši xān mün. 18. DOT, f. 15 .

dörböd dalai tayiši aүadān ejüülüqsēr (sic. eǰlüülüqsēr) aldaba. ǰarim kümün küböügēn manjougi alaqsār aldaba gedeq. jarim kümün čilēgēr aldaba [gedeq]. 
crushed the Khoshuuds under Ochir Tsetsen Khan and become the lord of all Oyirads in Central Asian steppe; and at that time, the Zunghars were in conflict with Chinese and Turkestanis. Here, the word China/Chinese (kitad) appears twice. Apparently, Ochir Tsetsen Khan's brothers mentioned above were the Khoshuud princes who moved to Qinghai and Tibet following Güüshi in the late 1630s. It is well-known that Güüshi was enthroned by the Dalai Lama as khan of Tibet in 1642, and the Khoshuud Khanate in Tibet was established as a result of integration and cooperation between the Khoshuud and Tibetan (esp. Gelugpa) nobles. ${ }^{19}$ In addition, during the time of the Khoshuud Khanate (1642-1717), the Khoshuuds and the Tibetans continued to interact with each other intensively and then were integrated in many aspects. ${ }^{20}$ Therefore, it is understandable that Ghabang Sharab considered the Khoshuuds in Tibet and Qinghai to have already become Tibetans.

What about the Khoshuuds becoming Chinese? First of all, with Galdan Boshugtu Khan's downfall in 1697, the Qinghai Khoshuud nobility led by Dashi Baatur submitted to the Kangxi emperor in a personal audience at Xi'an, receiving rich titles and gifts. ${ }^{21}$ Later, the Khoshuud Khanate in Tibet collapsed due to the invasion of the $\mathrm{Zu}$ nghars in 1716-1717, and after the Zunghar forces were finally expelled from Tibet by the Qing armies in 1720, all of Tibet officially became subordinate to the Qing Empire. Moreover, after Lubsang Danzin's rebellion was repressed by the Qing troops in 1724, the Qing government, following the recommendations of Nian Gengyao 年美堯, divided the Qinghai Mongols into twenty-nine banners in 1725, each under the direct supervision of the Manchu amban in Xining. ${ }^{22}$ Therefore, it is manifest that Ghabang Sharab regarded the Khoshuuds in Qinghai and Tibet to have become Chinese when describing their submission to the Qing Empire. In addition, the second quotation also leads to the same conclusion. Dalai Khung-tayiji was the second or sixth son of Güüshi $\mathrm{Khan}^{23}$ and dominated the Qinghai region. ${ }^{24}$ Therefore, in this passage, Ghabang Sharab again elucidated the fact that the Qinghai Khoshuuds submitted to the Qing Empire by putting words in the mouth of Dalai Khung-tayiji. Again, to Ghabang Sharab, submitting to the Qing meant becoming Chinese.

In the third passage, Ghabang Sharab described the Oyirad campaign to Qinghai and Tibet led by Güüshi Khan, and he praised it as an enormously meritorious feat for

19. Christopher P. Atwood, Encyclopedia of Mongolia and the Mongol Empire (New York: Facts on File, 2004), 574; Borjigidai Oyunbilig, “Heshuote hanting de jianli guocheng” 和碩特汗廷的建立過程, Neimenggu shehui kexue 內蒙古社會科學 1988.4: 72-73.

20. Elliot Sperling, "Pho-lha-nas, Khang-chen-nas, and the Last Era of Mongol Domination in Tibet," Rocznik Orientalistyczny 65.1 (2012): 203-8.

21. Atwood, Encyclopedia, 574.

22. Atwood, Encyclopedia, 574; Oyunbilig, "Heshuote hanting," 70.

23. Ghabang Sharab recorded that Dalai Khung-tayiji was the second son of Güüshi Khan. According to Tibetan sources, however, Dalai Khung-tayiji was his sixth son. For details, see DOT, f. 4; Sperling, "Pho-lha-nas, Khang-chen-nas," 199 n8.

24. Atwood, Encyclopedia, 574; Sperling, "Pho-lha-nas, Khang-chen-nas," 199n8. 
Tibetan Buddhism. Here, Ghabang Sharab also enumerated the names of the places deemed to have been heavily influenced by Güüshi's enterprise. That being so, the place names should represent the regions in which Tibetan Buddhism was practiced at the time of Ghabang Sharab. In light of this, it is odd that China was included in the list of place names because, at that time, China was not a region where Tibetan Buddhism was widely venerated. The only possible explanation for this anomaly is that Ghabang Sharab actually meant China here in the sense of the Qing Empire or the Manchu court. Around 1737, the Qing or Manchu court (not China per se) was considered not only the seat of Manjushri Bodhisattva but also the biggest patron of Tibetan Buddhism.

The fourth quotation is quite important because here we can find the only word reminiscent of the Manchus (i.e., manjou) in Ghabang Sharab's The History of the Four Oyirads. However, there is little possibility that the term manjou represented the Manchu people here. First of all, the Dörböd lands of Dalai Tayishi and his sons were located extensively between the north of Lake Balkhash and the Ural River, and some of them even reached up to the lower Ishim and Tobol Rivers in Siberia. ${ }^{25}$ Given the distance between the Dörböd and the Qing, it hardly makes sense that Dalai Tayishi of the Dörböd would have killed Manchu people. Moreover, it was only after 1688, when Galdan Boshugtu Khan of the Zunghar began to attack the Khalkha Mongols, that the Oyirads had their first military clash with the Manchus. Considering that Dalai Tayishi died around 1637, it was impossible for him to fight the Manchus after 1688 in support of Galdan Boshugtu Khan. Therefore, the word manjou must have meant something other than the Manchus in this passage.

What then did it mean? According to the Xiyu tongwen zhi 西域同文志, the eldest son of Dalai Tayishi was called "Minju." ${ }^{26}$ Considering the phonetic similarity, it is highly probable that minju in the Xiyu tongwen zhi actually signified manjou in The History of the Four Oyirads. That is to say, the term manjou in the fourth excerpt was the name of the eldest son of Dalai Tayishi, not the ethnonym Manchu. In conclusion, the author of The History of the Four Oyirads only utilized the term China (kitad) to designate the Qing Empire and the Manchu court.

\section{Evidence from Galdan Boshugtu Khan's Letters}

In the document collection of the Mongolian Office of the Grand Secretariat of the Qing Dynasty (Dayičing gürün-ü dotuүadu yamun-u mong $\gamma o l$ bičig-ün ger-ün dangsa

25. Borjigidai Oyunbilig, “17-shiji Weilate gebu youmudi yanjiu xu” 17世紀衛拉特各部游牧地研究續, Xiyu yanjiu 西域 研究 2010.2: 64; Michael Khodarkovsky, Where Two Worlds Met: The Russian State and the Kalmyk Nomads, 1600-1771 (Ithaca: Cornell University Press, 1992), 78, 89.

26. XTZ, vol. 4, Table II, "Dörbet." 
or Qing neige Menggutang dang 淸內閣蒙古堂檔), there are numerous diplomatic letters written in the Clear Script by the Zunghar rulers, such as Galdan Boshugtu Khan and Tsewang Rabdan. It is interesting to note that the Zunghar rulers did not use the term Manchu in their letters when they needed to mention the Qing Empire. Instead, a couple of Zunghar letters did employ the term China (kitad) to signify the Kangxi emperor and his empire.

[1] The eighteenth year of Kangxi (1679). A response to the ministries' document which was based on the khan's edict. The person who reported that the state of the Oyirads and the Mongols (oyirod mongyoliyin törö) broke down probably delivered false information. The state of the Oyirads and the Mongols is firm with the blessing of the Dalai Lama. [Other than this,] your edict and instruction are generally very correct. Except for only the Oyirads and the Mongols, aren't Russia (oros), Turkestan (xoton), Kazakh (tongmoq), and China (kitad) all in conflict? We also think that if all those countries follow the decree of the Dalai Lama, [all of them] will become peaceful. I was very pleased that [your] edict and instruction corresponded to our thinking. I wrote [this letter] from the Irtysh on a good day of complete auspiciousness. ${ }^{27}$

[2] The twenty-fifth year of Kangxi (1686). A letter submitted by Galdan Boshugtu Khan of the Ögeled. To Amughulang Khan the Serene Holiness, who completely and peacefully gives protection to the country of vast great China (kitad) by the power of the initial good merit . . ." 28

[3] A letter submitted by Galdan Boshugtu Khan of the Ögeled. To the Serene Holiness who is famous as the great Amughulang Khan, the jewel like [a great] mind who generally holds the work of the two customs (xoyor yosoni üyilesi) well and greatly satisfies all general [beings] with feasts of benefit and peace .... Now [I] understand this circumstance and think that it is good for everyone that the Four Oyirads and China (kitad) also conduct trade by following their own previous custom. [I] wrote [this letter] on the eleventh day of the eleventh month of the year of the fire tiger (1686). ${ }^{29}$

27. Mongol ulsyn ikh surguul' ekh bichig altaĭ sudlalyn tenkhim, trans. and ed., Daĭchin gürniü dotood yaamny mongol bichgiīn geriin dans (abbreviated DDMD; Ulaanbaatar: Soyombo printing, 2010), 2: 56, no. 2-27.

xāni ǰarligiyin esēr yāmunariyin bičigiyin xariu. oyirod mongүoliyin törö, ebderebe geji, medüülüqči kümün, xudal

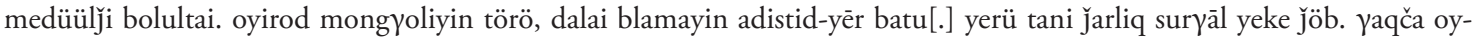
irod mongүol bisi, oros, xoton, tongmoq, kitad xa (sic. xā) čigi bese ebderel bei ülü bayinuu. tere ulus bügüdēr dalai blamayin ǰarliүār bolxuna, amur bolxuyigi bida čigi sananai. ǰarliq surłal mani sanānā, neyileqsen-dü yeke bayarlaba. beleq tögüsüqsen sayin ödür erčes-eče bičibe.

28. $D D M D$, 4: 132, no. 4-106.

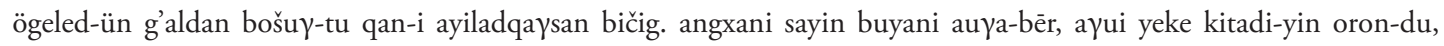
amur-yēr oүotu tedküqči, amuүuulang xāni gegēn-dü.

29. $D D M D, 6: 47$, no. 6-26.

ögeled-ün g'aldan bošuү-tu qan-i ayiladqaysan bičig. yerüde xoyor yosoni üyilesi sayitur barin, yerüngkei bügüde-dü 
In the first quotation, Galdan Boshugtu Khan denied the claim that the state of the Oyirads and the Mongols had broken down. ${ }^{30}$ To make a counter-claim, Galdan articulated that the criteria for a state to be firm and peaceful were whether or not a country followed the Dalai Lama's decree and whether the Dalai Lama blessed the state. Based on this principle, Galdan argued that for now, only the state of the Oyirads and the Mongols was firm, whereas the countries of non-believers, such as Russia, Turkestan, Kazakh, and China, were in distress. Here, Galdan Boshugtu Khan enumerated the names of the countries around the Zunghars. It is noticeable that the term Manchu was not included in this list of the countries. Therefore, it is possible to see that Galdan Boshugtu Khan and his people did not recognize Manchu as a separate ethnic or geographical unit. As seen in the previous chapters, the Manchus were probably identified as China or Chinese (kitad) in this letter as well.

The second passage also provides a very important insight. In this letter, Galdan Boshugtu Khan addressed the Kangxi emperor as "the protector (or supporter; tedküqcii) of the country of China (kitadi-yin oron)." That is to say, from the perspective of Galdan Boshugtu Khan, the Manchu emperor was the lord of China regardless of his ethnicity. In the third citation, Galdan Boshugtu Khan discussed the trade relationship through the tributary system and perceived the trade between the Zunghars and the Qing Dynasty as being practiced between the Four Oyirads and China (kitad). From these examples, it can be once again confirmed that the Oyirad people, including the Zunghars, referred to the Qing Empire and the Manchu court as China or Chinese. ${ }^{31}$ Also, these two passages indicate another crucial point. The Manchu translations of these documents invariably interpreted the Mongolian word "kitad" by the Manchu word "nikan." 32 Therefore, the Manchu emperor and his Manchu entourage must have known that the Zunghars identified the imperially privileged ethnic group (i.e., the Manchus) with their subjects (i.e., nikan, Chinese).

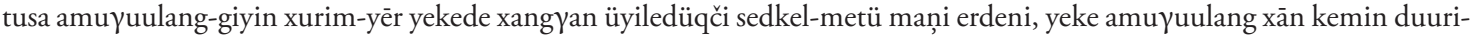
suqčiyin gegen-dü. . . odōči ene učiri meden, dörbön oyirod, kitad, kejēenei yosōron, xudaldan čigi urdu yosōr boluqsan[,]

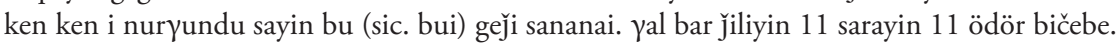

According to the Manchu translation of this document, this letter was written on the twelfth day of the eleventh month of the year of the red tiger (fulgiyan tasha aniya omšon biyai juwan juwe), that is, December 26, 1686. See DDMD, 5: 144, no. 5-33.

30. This claim that the state of the Oyirads and the Mongols broke down probably originated from the fact that Galdan of the Zunghar overthrew Ochir Tsetsen Khan of the Khoshuud in 1676 and was then enthroned as Galdan Boshugtu Khan in 1678 .

31. Here, it should be emphasized that when the Oyirad people utilized the term China (kitad) to signify the Qing Empire, the term did not include Tibet and Khalkha Mongolia even after those two lands became part of the empire. In Clear Script sources, Tibet and Khalkha Mongolia were always treated separately from China.

32. "ület i g'aldan bošogtu han $i$ wesimburengge. colgoroko sain hüturi hüsun $i$ onco amba nikan i oron de umesi elhe wehiyere elhe taifin han i genggiyen de" (DDMD, 4: 175, no. 4-149); “omšon biyai juwan duin de ület i g'aldan bošogtu han i wesimburengge. uheri juwe doroi baita be saikan jafame, gubci de tusa taifin i sarin i umesi elebure günin i gese mini erdeni amba elhe taifin han seme algika genggiyen de wesimbure ... te bicibe ere turgun be safi, duin oirat, nikan julgei songkoi oho hüdašarangge inu nenehe songkoi ohongge, yaya de amba muru gemu sain dere seme günimbi" (DDMD, 5: 144, no. 5-33). 


\section{The Manchus as Chinese: A Pejorative?}

Why did the Oyirads consider the Manchus to be Chinese? In this regard, there are several crucial documents worth investigating within the Mongolian document collection of the Inner Secretariat of the Qing Empire.

[1] April 28, 1645 (Shunzhi 2/4/3): To the holy khan (boyda qayan-a), Dorji Dalai Baatur sent [this] letter: "[You] seem to have been healthy and peaceful ever since [youl took the state of Great Ming (Da Ming 大明, dayiming-un törü). Here we are healthy." 33

[2] April 28, 1645 (Shunzhi 2/4/3): A letter of two queens, Khung-tayiji, Danjin, and Erdeni Dayiching. [We] sent [this letter] to the king of the Jin (Jin Wang 金 王, Jinwang): "Your letter and envoy arrived here. Formerly the letter of the khan of the Jurchens and later the letter of [his] child (urida jurcid-un qayan-u bičig, qoyin-a kegüken-ü bicig) said: 'I will enter the religion of the Buddha with piety! I will unite [deviants] who do not improve the harmony and peace of the world!' The word of the current envoy's letter seems to be unsatisfying to people's minds. A person who sends emissaries in the direction of the Three Jewels ( $y$ urban erdini) after obtaining what he wished and a figure who abandons arrogant mind after accomplishing what he intended will have the state of people who have good customs." ${ }^{34}$

[3] November 12, 1646 (Shunzhi 3/10/6): [I] presented [this letter] to the khan, the Serene Holiness of the Dayiching Ulus (dayicing ulus-un qayan-u gegen-e), the lord of all of his directions, who clearly had a plethora of splendor of great merits. [I,] the Dharma King and the Protector of the Religion (sasin bariyci nom-un qayan), say with a respectful mind: "Now, like the spirit of a hermit obtaining firm pleasure, happiness increased in [my] mind by hearing of the good reputation that the country of the Wheel-turning King (Chakravartin; kördün orčijuluycí-yin qan) came to splendidly materialize after [you] had waged war with and then sorted out [all] the directions that would not conform to the jewel body that originated from the splendor of countless merits; [after you] had sat on the secure lion throne of the khan of China

33. CDME, 2: 97, no. 30 .

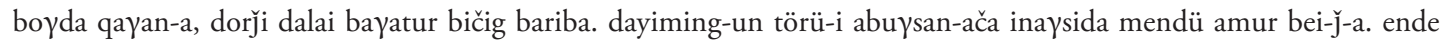
bida mendü.

34. $C D M E$, 2: 99, no. 31 .

qoyar qatun kiged, qung tayiǰi, bsdanǰin, erdini dayičing, eden-ü bičig. Jinwang-dur ilegebe. tan-u bičig elči ende kürčü irebe. urida jurčid-un qaүan-u bičig, qoyin-a kegüken-ü bičig, burqan-u šajin-dur süsüg-iyer oroy-a[,] yirtinčü-yin ey-e, ebiyan ǰasada $\gamma$-ügei-ber nigedduy-a gegsen bile. edügeki elči bičig-ün üge kümün-ü sedkil-dür ülü sanaүdaqu metü bayinam.

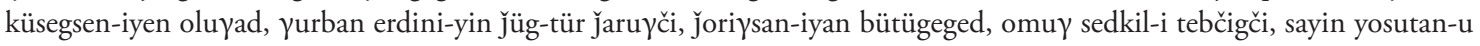
törü bolai. 
(kitad-un qayan-u ayul-ügei arslan-tu tabčang-dur sayuju); [after you] had venerated and worshipped the jewel of the religion of the Buddha; [after you] had raised all the commoners by taking care of and showing mercy to [them]; and [after you] had reduced groups of bad adversaries to dust." ${ }^{35}$

[4] November-December 1647 (Shunzhi 4/11): To the great khan, the Serene Holiness complete with the power having authority over people, Mergen Jinong presented [this] letter: "I was very happy to hear that the brightness of the khan (i.e., the Shunzhi emperor) was marvelous and that the sign of the religion and the great state (yeke törü) was peaceful. We are healthy here by the blessing of the high and holy Three Jewels. The incarnation of powerful Manjushri took the state of the great Dayiming khan (erketü manjusiri-yin qubilyan yeke dayiming qayan-u törü-yi abun), and you the khan possessed the Chinese Ulus (nanggiyas ulus). After our khan (i.e., Güüshi Khan) owned the Tibetan Ulus, as well as the religion and the state of the Chakravartin Dharma King, the incarnation of merciful Avalokiteshvara Bodhisattva, when you two khans united your religion and state, all of us were very happy." ${ }^{36}$

The passages above, all of which were composed by the Oyirad princes in Qinghai and Tibet, clearly indicate that the Oyirad people who had the earliest contacts with the Qing Empire thought that the Qing took over the state or rulership of the Ming Dynasty (dayiming-un törü) in 1644.

The second excerpt is quite interesting in that the Oyirad nobles who sent the letter to the Qing court in 1645 called the Qing rulers jinwang (i.e., king of the Later Jin Dynasty; referring here to the Shunzhi emperor) and khan of the Jurchens. It seems that in this passage, the "khan of the Jurchens" who had formerly sent a missive was Hong Taiji (i.e., the Chongde emperor), and his "child" who sent an epistle later represented the Shunzhi emperor. ${ }^{37}$ In fact, Hong Taiji sent a letter to Güüshi Khan on May 22,

35. CDME, 2: 177-78, no. 32 .

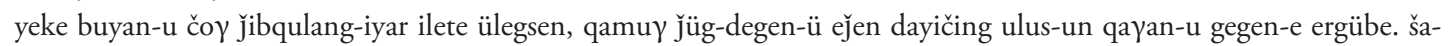

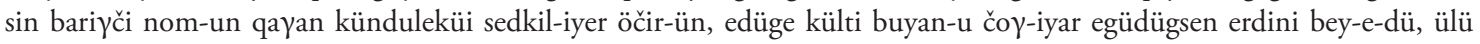

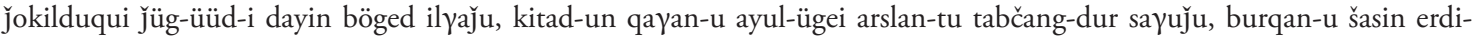

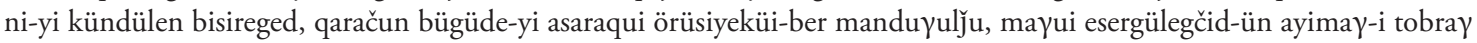

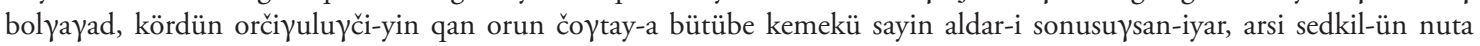
jiryalang-i oluүsan-metü, sedkil-dür bayasqulang nemebe.

36. $C D M E, 2: 417-18$, no. 24

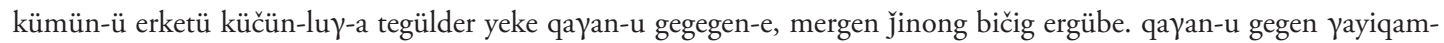

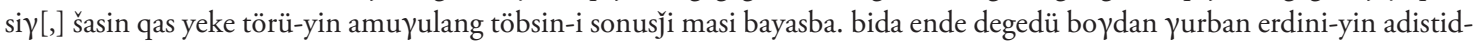
iyar mendü. erketü manǰusiri-yin qubil үan[,] yeke dayiming qaүan-u törü-yi abun[,] nanggiyas ulus-i qaүan či ejelebe. nigülesügči qonsim bodisung-yin qubilyan chakra wardi nom-un qaүan-u šasin törü[,] töbed ulus-i mani qayan eǰeleged, ta qoyar qaүan šasin törü-ben nigedügsen-dü bida bügüde masi bayasba.

37. Interestingly enough, the overall attitude of this letter toward the Qing rulers is negative and belittling, since the Shunzhi emperor here was referred to as Jinwang and as a child (kegüken), while Hong Taiji was called just the khan of the Jurchens. The reason why the Oyirad nobles showed such a depreciating tone could be inferred from the contents and context of this 
1643 (Chongde 8/4/5) to inform the new ruler of Tibet that he had exchanged envoys with high lamas in Tibet and supported both the Yellow and the Red sects of Tibetan Buddhism. In this letter, moreover, Hong Taiji addressed himself as "the holy khan of the Dayiching Ulus who shows vast mercy and is in harmonious relationships (dayičing ulus-un ayuda örüsiyegči nayiramdaqu boyda qayan)." ${ }^{38}$

In light of these circumstances, it is possible to conclude that the Oyirads already knew the Qing Dynasty and its rulers were originally not Chinese. They were undoubtedly aware of the facts that the Manchus were previously called Jurchens (jurcid), and the state of the Jurchens was earlier known as Jin 金. Therefore, the Oyirad nobles who wrote this letter considered Hong Taiji, who died before the Qing conquered China, to be just a khan of the Jurchens (not China), although Hong Taiji previously called himself the holy khan of the Dayiching Ulus.

In the third passage, Güüshi Khan demonstrated that the Shunzhi emperor established the country of the Chakravartin by means of quelling nonconformists, sitting on the throne of the khan of China (kitad-un qayan-u . . tabcrang), and worshipping the religion of the Buddha. Likewise, the fourth quotation states that the Manchu emperor, as an incarnation of Manjushri, assumed the state or rulership of the great Dayiming khan (yeke dayiming qayan-u törü) and thus possessed the country of China (nanggiyas ulus). Given the passages above, it is plausible that the Oyirad view of the rulers of the Jurchens or the Manchus changed around 1644 when Manchu forces broke through Shanhai Pass and occupied Beijing. In other words, prior to 1644, the khans of the Qing Empire (dayičing ulus-un qayan) were simply deemed khan of the Jurchens by the Oyirads. When the Shunzhi emperor became the unquestioned lord of Beijing and most of China proper from 1644 on, however, the Oyirads acknowledged that the Qing emperor successfully assumed rule of the state of Dayiming, and then elevated the Qing ruler from khan of Jurchens to khan of China.

Here, it is noteworthy that the terms related to China (e.g., kitad and dayiming) do not necessarily have negative connotations in the Mongolian chronicles of the seventeenth century. First, when it comes to the word China, the Mongolian sources written in western Inner Mongolia, such as The Precious Summary and The Jewel Translucent Sutra, often depicted China as something desirable, although they sometimes described China also as the opponent in military conflicts. For example, in The Precious Summary, the Dalai Lama considered Ming China (kitad-un dayiming) as a great country equiva-

letter. In this document, the Oyirad princes pointed out that the content of the current missive from the Qing side was not satisfactory, and in order to have a state of good customs, a ruler should have delivered respect to the high lamas in Tibet and should not have been conceited after achieving great success. From this fact, it is possible to assume that the Oyirad nobles indirectly criticized the Qing court in this letter because, after the conquest of China, the Qing ruler did not send envoys to Tibet and instead acted arrogantly. For this reason, in this epistle, the Oyirad princes did not acknowledge the Qing emperor as the official holder of the state of Dayiming of China, and hence called him Jinwang and a child.

38. $C D M E, 1: 378-79$, no. 12. 
lent to the Mongol Ulus (kitad mongyol qoyar yeke ulus). ${ }^{39}$ In the same chronicle, China was deemed a counterpart ulus with which the Mongol ulus united to form a greater state (yeke törü) after Altan Khan made peace with the Ming in $1571 .^{40}$ The same view on China is witnessed in The Jewel Translucent Sutra as well. ${ }^{41}$ Moreover, almost all the Mongolian chronicles recognized emperors of the Ming Dynasty (dayiming qayan) as someone auspicious and having great fortune and fate. For instance, the founder of the Ming Dynasty, Zhu Yuanzhang, was described as being born with a rainbow over his house; ${ }^{42}$ the Yongle emperor was considered the son of Toghon Temür Ukhaatu Khan, the last emperor of the Mongol Empire, and his Khonggirad empress; ${ }^{43}$ and the Ming emperor who was captured by Esen Tayishi of the Oyirad in 1449, reportedly, emanated yellow and red lights when he fell asleep and also caused cattle-plague, starvation, pestilence, and calamity among the Mongols. ${ }^{44}$ Lastly, The Precious Summary associated even Chinggis Khan's supreme status with China (e.g., kitad and dayiming) by stating as follows: "Chinggis Khan of the Mongols expelled the Manchu Golden Khan of China (kitad-un manzu altan qayan), took over his state, and ... after subjugating the thirteen provinces of the Eighty Tümen China (nayan tümen kitad-un arban yurban muji), the red ulus, became renowned as Chinggis Khan the Divine Majesty of Dayiming (dayiming sutu boyda činggis qayan)." 45

In light of these factors, it is cogent to argue that the Oyirads did not mean to disparage a Manchu emperor and his Manchu people when they called the Manchus Chinese. Rather, the Oyirads actually intended to exalt the Manchu emperor by acknowledging him as the khan of China because the Oyirad people regarded khan of China as a prestigious title and bearing elevated status. In other words, for the Oyirads, calling a Manchu ruler and his people Chinese was an acknowledgment and glorification. A very similar viewpoint is also found in The Precious Summary: it reads, the Shunzhi emperor, "having been seated on the golden throne of the Dayiming khan of China (kitad-un dayiming qayan-u altan siregen degere sayuju) in 1644 , became famous as the ruler of harmony (eyeber jasayči $i)^{46}$ in all directions .... And then [he] put in order the entire great country (gür yeke ulus) from its foundation and made the great state of jade (qas yeke

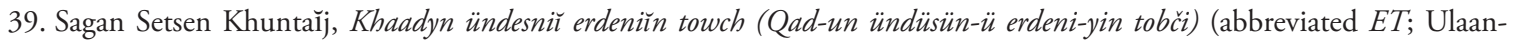
baatar: Bolor Sudar, 2011): 172:83v.

40. ET, 163:70r, 166:74r.

41. For details, refer to Johan Elverskog, The Jewel Translucent Sutra: Altan Khan and the Mongols in the Sixteenth Century (Leiden: Brill, 2003): 127-28.

42. Charles Bawden, The Mongol Chronicle Altan Tobchi: Text, Translation, and Critical Notes (abbreviated AT; Wiesbaden: Harrassowitz, 1955), 149-50; ET, 147:46r; Jamba/Shamba, Asragch nertiün tüükh (asarayči neretü-yin teüke) (abbreviated

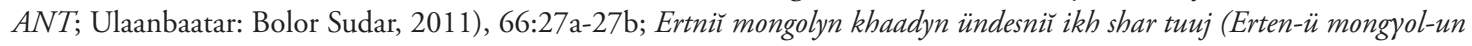
qad-un ündüsün-ü yeke sir-a tuүuji) (Ulaanbaatar: Bolor Sudar, 2011), 88:11b.

43. AT, 155; ET, 179:94r; ANT, 67:29b.

44. $A T, 173-74 ; E T, 156: 59$ r.

45. ET, 139:35r.

46. The term "eyeber jasayći” is Shunzhi’s reign title in Mongolian. It has the same meaning as the Chinese term Shunzhi 順 治. 
törü) peaceful." ${ }^{77}$ In sum, the Oyirads began to call the Manchu ruler and his people not Jurchens but Chinese to appreciate their great achievement of conquering China in the mid-seventeenth century. Once this way of naming the Manchus was established among the Oyirads, they probably continued to stick to the term China or Chinese to refer to the Manchus.

In this respect, The Biography of Zaya Pandita also provides an interesting example. On his way back to the land of the Oyirads from his pilgrimage to Tibet, Zaya Pandita had an audience with the Dalai Lama, who was then on his way to Beijing, in Qinghai in 1651 .

And then, after [Zaya Pandita] came to Kökö-nour (i.e., Köke-nayur = Qinghai) in advance, he waited for one month. At that time, the great and lesser princes led by Dalai Khun-tayiji [received] the lama the Serene Holiness (i.e., the Dalai Lama), built a platform in [a place called] Shabartai which was on the edge of Kökö-nour, and made all the people prostrate themselves [before the Dalai Lama]. At that time, [Zaya Pandita] also greeted the lama the Serene Holiness and spoke respectfully to him for the sake of benefit of the religion and living beings: "In general, among the people speaking Mongolian languages, there is no [person] greater than the holy khan of the Jurchens ( ̌̈̈rrčidiyin boqdo xān). Because [the khan] does not transgress your word, if [you] say to the khan, 'Spread Mongolian letters and other Mongolian teachings!' it would be good." Then, the lama the Serene Holiness made a smile and said "Although you are right, [he] is a haughty khan (omogtoi xän amui). When I reach [him], I will deal with [it]!" [Later, Zaya Pandita] said to us, "It is true that [the Dalai Lama] clearly said he would also not venerate the khan (xäni ülü süjülküi)."”48

In this passage, Zaya Pandita, his disciples, and the Dalai Lama characterized the Qing emperor in a rather negative way. It is doubtful, however, that Zaya Pandita and the Dalai Lama really said such words as "the holy khan of the Jurchens," "a haughty khan," and "he would also not venerate the khan," because the author of this biography manifestly revealed a specific intention in this excerpt. In other words, Radnaabadraa, while writing this biography of his deceased master around 1691, in order to secure the survival of his order, needed to rebuff the suspicion that his guru previously had not only a close relationship with, but also a submissive attitude toward, the Qing emperor. As

47. ET, 180:95r-95v.

48. Biography of Zaya Pandita, 109:14v.

tegèd kökö nour-tu urid kürči irēd nigen sara külëbei. ten=de blamayin gegēgi dalai xong tayiji terigüülen yeke baya noyon kökö nouriyin köbō šabartadu (sic. šabartaidu) yengder yasaǰi xamuq bügüdüi mörgüülbei. tende basa blamayin

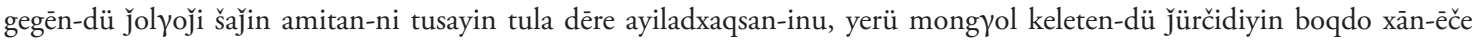

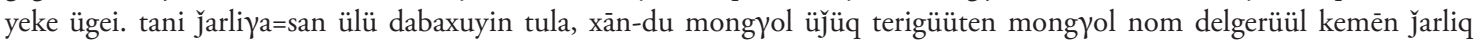
bolxu=nan sayin aqsanǰi kemēn ayiladxaq=san-du, blamayin gegēn müšēn üyiled=či činei jöb bolbuču omoqtoi xān amui. kürči medeye kemēn ǰarliq bolboi. tere čü xāni ülü süjülküi ilerkei ayiladuqsan mün amui kemēn mandu ǰarliq bolboi. 
a matter of fact, from 1688 on, the Zunghar ruling elites continuously suspected the order of Zaya Pandita's disciples of treason, and eventually they were severely persecuted by a Zunghar noble as known as Noyon Gelong. ${ }^{49}$

In this situation, one of the main reasons for Radnaabadraa to compose this biography of the great Oyirad lama was to legitimate and thus secure the survival of Zaya Pandita's order in an unfavorable atmosphere under the Zunghars..$^{50}$ Moreover, in 1691, the Zunghars led by Galdan Boshugtu Khan continued to be in a hostile relationship-if not an actual war-with the Qing Empire. In light of these circumstances of the time, one of the effective strategies Radnaabadraa could employ in his writing was to deny the existence of any close or submissive relationships between his order and the Qing Empire. ${ }^{51}$ For this reason, Radnaabadraa disapproved of the Qing emperor in this section by putting the words "the Qing emperor is a haughty khan" and "the Dalai Lama would also not venerate the khan" into the mouths of the Dalai Lama and Zaya Pandita respectively. Although it is the Dalai Lama that depicted the Qing emperor as an arrogant khan and declared he would not revere the emperor in the passage, Radnaabadraa's real aim hidden between the lines was to claim that Zaya Pandita and his order had neither a friendly relationship with (due to the arrogance of the emperor) nor an obedient attitude toward him (since both Zaya Pandita and the Dalai Lama would not venerate the emperor).

Given the negative tone toward the Qing emperor in this excerpt, it is noteworthy that Zaya Pandita reportedly addressed the emperor as "the holy khan of the Jurchens (jürčidiyin boqdo xān)," while depicting the emperor as a greater lord than any other Mongol rulers. It is possible that Zaya Pandita, who visited the Qing court as a head of the Oyirad tribute mission and met the Qing emperor in person in 1647, did magnify the Qing emperor as a greater ruler than all Mongol khans and princes when he asked the Dalai Lama to deliver his words to the emperor in 1651. Recording this event, however, Radnaabadraa may have subtly changed Zaya Pandita’s exact wording to achieve

49. Biography of Zaya Pandita, 165:42v-175:47v.

50. According to The Biography of Zaya Pandita, Noyon Gelong killed a number of the order's lamas in 1689 and 1691 . See Biography of Zaya Pandita, 167:43v, 173:46v-174:47r.

51. To this end, Radnaabadraa even fabricated a historical fact in the biography. According to The Biography of Zaya Pandita, in the summer of 1647, Tsetsen Khan gathered ten thousand geldings and then dispatched one hundred people to China with Khonjin Lama of the Mongols (mongyol xonjin blama) as their head (see Biography of Zaya Pandita, 96:8r-97:8v). The Veritable Records, however, clearly indicated that Rabjamba Khutugtu (i.e., Zaya Pandita) and Changzodba Darkhan Tsorji led the Oyirad tribute envoys at that time (see Veritable Records, vol. 35, Shunzhi 4/11/21 [丁巳]). Furthermore, according to $C D M E$, Khonjin Lama (erdini qonjin blam-a) headed Ochirtu Tayijis envoys to the Qing court not in 1647 but in 1650 (see $C D M E, 3: 117-19$, no. 8-9). Therefore, it is logical to see that it was not Khonjin Lama but Zaya Pandita that actually led the Oyirad tribute mission and had an audience with the Qing emperor in Beijing in 1647, as opposed to the claim in The Biography of Zaya Pandita. Here, Radnaabadraa's purpose is clear. In his writing, he replaced Zaya Pandita as a leader of the 1647 Oyirad envoys with Khonjin Lama, who in fact visited the Qing court three years later. By doing so, he attempted to conceal that his master visited the Qing court as head of Ochirtu Tayiji's envoys, met the Qing emperor in person, and presented the emperor a memorial and horses in 1647. In sum, Radnaabadraa tried in the biography to erase the close relationship that once existed between Zaya Pandita and the Qing court. 
his purpose of de-emphasizing the close and favorable relationship that Zaya Pandita once cultivated with the Qing emperor. In other words, the author of the biography probably inserted the word "of the Jurchens (jürčidiyin)" into Zaya Pandita's actual utterance to make Zaya Pandita depreciate the magnitude of the Qing emperor. If this analysis of the passage is tenable, it is plausible to conclude that for the Oyirad people, calling a Manchu ruler a "khan of the Jurchens (not khan of China)" was pejorative toward the Manchus around 1691.

\section{The Term Manchu among the Oyirads}

The ethnonym Manchu began to appear in Oyirad Clear Script sources written after the collapse of the Zunghar state in 1755. The earliest Clear Script material which utilized the term Manchu is The Tale of the History of the Four Oyirads by an anonymous Dörböd author (probably written at the end of the 1750s). In this work, the term Manchu was written in various ways; for example, "manzuu or manzu," ${ }_{2}$ "manju," 53 and "manji." 54

Why was the word Manchu written in such different spellings here? To begin with, Oyirad writings are notoriously inconsistent in their orthography because, first, the Clear Script was devised to reflect the actual pronunciation of the Mongolian language and its various dialects of the seventeenth century; ${ }^{55}$ second, most Oyirad writers used the script in that spirit, writing words as spoken; and, third, in terms of spelling, colloquial forms were mixed with bookish forms in Oyirad written sources. ${ }^{56}$ As a result, a lot of different spellings for a single word occur in Oyirad writings. Moreover, generally speaking, the orthography of Oyirad Clear Script writings can be located somewhere between classical written Mongolian and modern Khalkha Mongolian. The word for Manchu is written "manju" in classical written Mongolian, while it is written and pronounced "manji" in modern Khalkha Mongolian (e.g., "Манж" in Cyrillic). Lastly, although there was no distinction between " $\mathrm{j}$ " and "z" sounds (likewise between "ch" and "ts") in the regular letters of the Clear Script in the seventeenth and the eighteenth centuries, it is likely that such phonetic differentiations began to take place as early as the seventeenth century in the Oyirad language. ${ }^{57}$ Therefore, it is possible to see that

52. Dörwön oüradyn tü̈kh tuuj khemeen orshiw \& Dörwön oüradyn namtar orshwoi, ed. Na. Sükhbaatar and Kh. Byambajaw (abbreviated DOTT; Ulaanbaatar: Tod nomyn gerel töw and Soyombo printing, 2016), 50:12v.

53. DOTT, 75:25r, 80:27v, 84:29v.

54. DOTT, 53:14r, 57:16r, 61:18r, 68:21v.

55. György Kara, Books of the Mongolian Nomads: More than Eight Centuries of Writing Mongolian (Bloomington: Research Institute for Inner Asian Studies, Indiana University, 2005), 145, 149.

56. Kara, Books of the Mongolian Nomads, 148.

57. Kara, Books of the Mongolian Nomads, 149-50; Khaltaryn Luwsanbaldan, Tod üseg tü̈niu dursgaluud, nemj bayajuulsan khoyor dakh' khewlel (Ulaanbaatar: Admon, 2015), 57. 
the Dörböd people, who had lived in Zunghar territory before they defected to the Qing domain in 1752-1753, pronounced the word manju sometimes with the " $\mathrm{j}$ " sound and other times with the "z" sound, to wit, "manju/manji”" and "manzu," respectively. In addition, the unknown Dörböd author of The Tale of the History of the Four Oyirads was knowledgeable enough to employ an Oyirad Galig (i.e., transcription) letter to denote the phonetic difference between "j" and "z." ${ }^{8}$ For these reasons, the Dörböd chronicle contained all of the different spellings for the term Manchu. The numerous renderings of the word, however, had only one meaning, the Manchus.

It seems that the term Manchu began to be in circulation among the Oyirads during the Zunghar period. First of all, The Tale of the History of the Four Oyirads, composed right after the collapse of the Zunghar state, indeed used the word Manchu, albeit in various forms. Moreover, the Yongzheng emperor demonstrated that the Zunghars called the Manchus Manzi in his Dayi juemi lu. Lastly, there are many depositions made by Zunghar fugitives to the Qing. In these reports, Zunghar refugees often differentiated the Manchus from the Khalkha Mongols and Chinese. ${ }^{59}$ Therefore, the Oyirads within the Zunghar state probably heard of the ethnonym Manchu and began to utilize the term by the time of the Yongzheng emperor (r. 1723-1735).

Although the term Manchu probably entered Oyirad vocabulary by the first half of the eighteenth century, this new word never completely replaced the term China (kitad) in reference to the Qing and the Manchus. Rather, Oyirad writers still utilized the word China more often than Manchu in discussing the Qing and the Manchus, even after the ethnonym Manchu was introduced to them. For instance, The History of the Four Oyirads composed by Baatur Ubashi Tümen in 1819-1820 never mentioned the word Manchu. Instead, the author only utilized the term China ( $k i t a d)$ for the events related to the Qing Empire. ${ }^{60}$ Likewise, The Tale of the Origin of the Mongols written in 1825 only employed the word China (kitad) with regard to the Manchus. ${ }^{61}$ Moreover, The History of the Origins of Holy Chinggis Khan, the Four Oyirads, and the Khoshuuds, writ-

58. In addition to the regular letters of the Clear Script for writing Mongolian and Oyirad words, Zaya Pandita devised two sets of the Galig (i.e., transcription) scripts to render all the different letters of Sanskrit and Tibetan. These Oyirad Galig letters were explained in such books as Tarni ungšixu arya xurāqsan, Olon nomiyin ündüsün üjü̈iyin ilyal, and Üü̈giyin nayirlay-a, which Zaya Pandita translated or composed. For details, see Luwsanbaldan, Tod üseg tü̈̈nĭ dursgaluud, 32.

59. For example, see the following documents preserved in the First Historical Archives of China: "Zoubao guixiang Wulianghai Kuxige dengren zhi kougong zhe” 奏报归降乌梁海库希格等人之口供折 (Yongzheng 9/6/14, no. 03-0173-1107-004); “Baosong zi Zhunga'er lai toucheng zhi Wulianghai Wulumu deng kougong dan” 报送自准噶尔来投诚之乌梁海乌 鲁木等口供单 (Yongzheng 10/12/12, no. 03-0173-1134-007); “Zou jiang toucheng zhi Elute Ha'erchahai shenming jiewang jingshi zhe” 奏将投诚之厄鲁特哈尔查海审明解往京师折 (Yongzheng 11/10/20, no. 03-0173-1150-014). There are far more documents than these three containing testimonies in which Zunghar runaways differentiated the Manchus from the Mongols and Chinese.

60. Baatar Uwsh, Dörwön oüradyn tü̈̈h orshiw, ed. B. Tüwshintögs and Na. Sükhbaatar (Ulaanbaatar: Tod nomyn gerel töw and Soyombo printing, 2006).

61. Mongolyn ug ekhiün tuuj, ed. Na. Sükhbaatar and M. Ulaan (Ulaanbaatar: Tod nomyn gerel töw and Soyombo printing, 2014). 
ten anonymously probably in the 1850 s, only used the term China (kitad) to denote the Qing Empire and the Manchus as well. ${ }^{62}$

In addition, The History of Kho Örlüg, which was probably written at the end of the eighteenth century, employed both the terms China and Manchu. This source is particularly interesting due to the way its author utilized the words under discussion. To be specific, in the section concerning Galdan Boshugtu Khan fighting the Qing Empire, this chronicle denoted the Kangxi emperor as "khan of China (kitad-un qayan)."63 In another passage discussing the military situation between the Zunghars and the Qing during the first decade of the eighteenth century, Ayuki Khan of the Torghuud reportedly said: "Certainly, the Zunghars threaten the khan of Manchu China (manju kitad-un qayan-i) on that side." ${ }^{44}$ According to another section regarding the situation after the downfall of the Zunghars, the Dörböds remained peaceful and unharmed "after [they] submitted to the Manchus (manju-du oruju öggüged)." ${ }^{5}$ These examples reveal that in The History of Kho Ölïg, the terms for the Manchus and the Qing Empire changed according to the times the author was describing: that is, China (for the late seventeenth century) $\rightarrow$ Manchu China (for the early eighteenth century) $\rightarrow$ Manchu (for the mid-eighteenth century). This transition might reflect how the word Manchu was introduced and adopted among the Oyirad people during the seventeenth and the eighteenth centuries. Lastly, The History of the Kalmyk Khans (written after 1819) also used both the terms China (kitad) and Manchu (mangzi, mangzu) for the Manchu emperors and the Qing Empire. ${ }^{66}$ In conclusion, the ethnonym Manchu was introduced to the Oyirad people in the Zunghar state probably by the early eighteenth century. Since then, usage of this word increased gradually among the Oyirads, and yet the word Manchu was never fully substituted for the term China, which Oyirad writers continued to use as before. For this reason, the Oyirads came to utilize both China and Manchu to refer to the Qing Empire and the Manchus.

62. "Bogd chingis khaany ug, dörwön oŭradyn ug, khoshuudyn ugiǐn tüükh bichig," in Oǐrad mongolyn tüükhend kholbogdokh surwalj bichgü̈̈d III, ed. Na. Sükhbaatar (Ulaanbaatar: Soyombo printing, 2002), 54-68; "Boүda činggis-un törü-yi bariүad qaүan örgüge tedkügsen tuүuji," in Mongyol kitad qarilčayuluysan todu üsüg-ün oyirad mongyol-un teüke-yin surbulji bičig-ü̈̈d 蒙汉对照托忒文字卫拉特蒙古历史文献译编, ed. Liǰei (Ürümchi: Sinǰiyang-un arad-un keblel-ün qoriy-a, 2009), 41-51.

63. "Kho örlögiĭn tüükh," in Ǒrrad mongolyn tü̈̈khend kholbogdokh surwalj bichigü̈d II, ed. Na. Sükhbaatar (abbreviated KOT/Sükhbaatar; Ulaanbaatar: Soyombo printing, 2001), 159; “Qo-örlüg-ün teüke," in Mongyol kitad qarilčayuluysan todu üsüg-ün oyirad mongyol-un teüke-yin surbulji bičig-ü̈̈d (abbreviated KOT/Lijei), 53.

64. KOT/Sükhbaatar, 159; KOT/Lijei, 54.

65. KOT/Sükhbaatar, 162; KOT/Lijei, 54.

66. Stephen A. Halkovic, Jr., The Mongols of the West (Bloomington: Research Institute for Inner Asian Studies, Indiana University, 1985), 189, 195. 


\section{Conclusion}

As discussed above, the Oyirad people employed both of the words China (kitad) and Manchu (manju, manji, manzu, mangzu, mangzi) to denote the Manchus and their empire. Before the Manchus conquered China proper, the Oyirad people recognized the Manchus and their state simply as the Jurchens and the Jin 金. After the Manchus succeeded in occupying Beijing and then most of China proper, the Oyirads began to refer to the Manchu emperor as khan of China (kitad-un qayan) who took over the state of Dayiming (dayiming-un törü, dayiming qayan-un törü). By doing so, the Oyirads did not mean to disparage the Manchus and their empire. ${ }^{67}$ By contrast, the Oyirad people acknowledged the great achievement of the Manchu ruler and accepted his elevated title and political (and often religious) status. That is to say, it was actually a major elevation of the Manchus when the Oyirads changed the title of their ruler from khan of the Jurchens to khan of China. Since then, the Oyirad people continued to call the Qing Empire and the Manchu court China or Chinese, as witnessed in The Biography of Zaya Pandita, Galdan Boshugtu Khan's Clear Script letters, and Ghabang Sharab's The History of the Four Oyirads. By the early eighteenth century, however, the term Manchu likely entered the land of the Zunghars. Even though usage of this new word grew among the Oyirad people over time, the Oyirads never abandoned their custom of referring to the Qing and the Manchus as China or Chinese. Therefore, in later Oyirad writings, the terms China and Manchu were used at the same time.

From the perspective of the Oyirad people, there was no intention to disparage the Manchus when the Oyirads called the Manchus Chinese. The Manchus, however, misunderstood the Oyirads for their own reasons. As seen in the Manchu translation of Galdan's letters, the Manchus surely knew that the Oyirads called their ruler khan of China and their empire China. From the early eighteenth century on, some of the $\mathrm{Oy}$ irad people began to call the Manchus "manji." This new mode of representation on the part of the Oyirads must have confused the Manchus. Since the Manchus already knew that the Oyirads called them Chinese (kitad), it was natural for the Manchus to associate the new word manj $i$ with something Chinese when figuring out the meaning of the new term. Probably, for this reason, the Manchus, including the Yongzheng emperor, interpreted manji $i$ as the time-honored pejorative for southern Chinese (i.e., manzi 蠻 子), which was once widely used by the Mongols of the Yuan Dynasty. ${ }^{68}$

67. As discussed earlier, the Oyirads utilized such terms as Jurchens and Jin—again, not Chinese and China-when they intended to belittle the Manchus and their empire.

68. Some knowledgeable readers might find it somewhat striking that the Yongzheng emperor was probably so unfamiliar with Mongolian that he could not figure out what "manji”" in the mouth of the Oyirads was referring to. To the best of my knowledge, however, there is no direct evidence indicating that the Yongzheng emperor had a good command of Mongolian. Moreover, it is noticeable that although he must have had plenty of dealings with various Mongolian peoples, almost all Mongolian affairs were actually processed using the Manchu language during the Yongzheng reign. Interestingly enough, down to the early Kangxi era, there was a considerable amount of Qing archival documents existing only in Mon- 
The translation of manji to southern Chinese, however, was a total misconception. The Oyirad expression manji had nothing to do with Chinese because the Oyirads pronounced the word Manchu (manju) in various ways, and manji was just one of the phonetic variants. Moreover, considering that more than three hundred years had already passed since the fall of the Yuan Dynasty, it is barely conceivable the Oyirad people of the eighteenth century had a clear understanding of what "manzi 蠻子” really meant. In other words, the Oyirads did not have any intention of deriding the Manchus when they called them manji. As in the case of the Oyirads calling the Manchus Chinese, the Oyirads probably also intended to give a positive meaning to the term manji. A passage of The Tale of the History of the Four Oyirads evidently associated the word manji with Manjushri Bodhisattva. It reads,

Afterward, at the time when the Four Oyirads have again come into being, then in the land of Black China, which is the seat of the Five Manjushris (tabun manzuširiyin sire xaran kitidin orun-du), the self-forming white mound (or white fortress; čaya kerim) ${ }^{69}$ is to manifest itself again. Thereupon, in the land of China, incarnations of the Five Manjushris take possession of this land and sit on the throne as great khans renowned as the khan of the Manji (manjin xan kemen aldarte yeke xan). ${ }^{70}$

\section{Bibliography}

Atwood, Christopher P. Encyclopedia of Mongolia and the Mongol Empire. New York: Facts on File, 2004.

Baatar Uwsh. Dörwön ǒrradyn tü̈̈kh orshiw. Edited by B. Tüwshintögs and Na. Sükhbaatar. Bibliotheca Oiratica II. Ulaanbaatar: Tod nomyn gerel töw and Soyombo printing, 2006.

golian versions (see $C D M E$, vols. 1-7; and $D D M D$, vols. 1-2). Therefore, it is indubitable that Kangxi's Mongolian was good enough to deal with various official affairs only in Mongolian. From about 1680 (Kangxi 20) on, however, almost all the Qing documents dealing with Mongolian and Tibetan affairs were written both in Mongolian and Manchu, and documents that existed only in Mongolian versions were very rare (see DDMD, vols. 2-21). That being so, it is reasonable to see that following 1680, Mongolian documents from Mongolia and Tibet were first translated into Manchu, and the Qing court then handled Mongolian and Tibetan matters using those Manchu translations. For this reason, it is probable that the Yongzheng emperor did not need to know Mongolian very well. Since the word for Manchu was written and pronounced strictly as "manju" in the Manchu language, Manchu people who did not know colloquial Mongolian of the time well probably could not understand clearly the Oyirads saying "manjui."

69. The word "čaja kerim (< čajan kerem)" usually means the Great Wall of China in Mongolian. The Great Wall, however, has nothing to do with Tibetan Buddhism and Manjushri Bodhisattva in terms of symbolism or metaphor. Therefore, ca a a kerim as the Great Wall makes less sense in this context. For this reason, I would prefer to make a literal translation of the term; that is, white mound or white fortress. In the regions where various Mongolian peoples have lived, as well as in Tibet, it is indeed possible for a white mound to have a religious meaning and function. For example, there are cairns all over in Mongolia and Tibet (i.e., obuy-a, owoo, or obo in Mongolian). Moreover, if this is interpreted as a white fortress, it could represent a white stupa, which is very common in the entire regions in which Tibetan Buddhism has been practiced. 70. DOTT, 56:15v-57:16r.

xoyino dakin dörbön oyirad boluqsen tere üye tere čaqtu[,] tabun manzuširiyin šire xaran kitidin orun-du eberen büteqsen čaja kerim basa eberen toqtuxu[.] teged kitidiyin oron-du tere širedü tabun maņzuširiyin xubil manǰin xan kemen aldarte yeke xan suuji bi bui. 
Bawden, Charles. The Mongol Chronicle Altan Tobchi: Text, Translation, and Critical Notes. Wiesbaden: Harrassowitz, 1955. Abbreviated AT.

"Bogd chingis khaany ug, dörwön oŭradyn ug, khoshuudyn ugiĭn tüükh bichig." In Ořrad mongolyn tüükhend kholbogdokh surwalj bichgüüd III, edited by Na. Sükhbaatar, pp. 54-68. Ulaanbaatar: Soyombo printing, 2002.

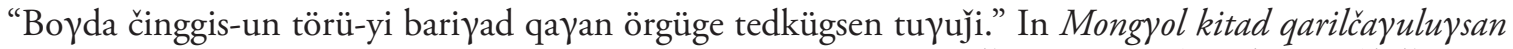
todu üsüg-ün oyirad mongyol-un teüke-yin surbulji bičig-ü̈̈d 蒙汉对照托忒文字卫拉特蒙古历 史文献译编, edited by Lijei, pp. 41-51. Ürümchi: Sinǰiyang-un arad-un keblel-ün qoriy-a, 2009.

Borjigidai Oyunbilig. “17-shiji Weilate gebu youmudi yanjiu xu”17世紀衛拉特各部游牧地研究續. Xiyu yanjiu 西域研究 2010.2: 63-68.

. “Heshuote hanting de jianli guocheng”和碩特汗廷的建立過程. Neimenggu shehui kexue 內蒙古社會科學 1988.4: 70-74.

Cheng Chongde 成崇德, translator. “Zaya bandida zhuan” 咱雅班第达传. In Qingdai Menggu gaosengzhuan yiji: Zhongguo bianjiang shidi ziliao congkan Menggu juan 清代蒙古高僧传译辑: 中国边疆史地资料丛刊 蒙古卷, edited by Zhongguo shehui kexueyuan Zhongguo bianjiang shidi yanjiu zhongxin 中国社会科学院 中国边疆史地研究中心, pp. 1-86. Beijing: Quanguo tushuguan wenxian suowei fuzhi zhongxin, 1990.

Dayi juemi lu 大義覺迷錄. Taibei: Wenhai chubanshe, 1966.

Dörwön ŏradyn tü̈kh tuuj khemeen orshiw \& Dörwön oüradyn namtar orshwoi. Edited by Na. Sükhbaatar and Kh. Byambajaw. Bibliotheca Oiratica LX. Ulaanbaatar: Tod nomyn gerel töw and Soyombo printing, 2016. Abbreviated DOTT.

Dumdadu ulus-un nigedüger teüke-yin dangsa ebkemel-ün sang, Öbür mong $\gamma$ ol-un öbertegen jasaqu

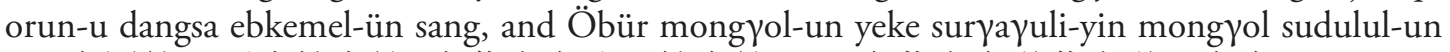
töb 中国第一历史档案馆, 内蒙古自治区档案馆, and 内蒙古大学蒙古学研究中心, editors. Čing ulus-un dotujadu narin bičig-ün yamun-u mongyol dangsa ebkemel-ün emkidkel 清内秘书院

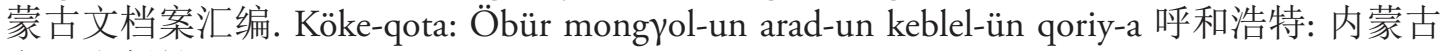
人民出版社, 2003. Abbreviated CDME.

Elverskog, Johan. The Jewel Translucent Sutra: Altan Khan and the Mongols in the Sixteenth Century. Leiden: Brill, 2003.

Ertniü mongolyn khaadyn ündesniü ikh shar tuuj (Erten-ü mongyol-un qad-un ündüsün-ü yeke sir-a tuүuji). Ulaanbaatar: Bolor Sudar, 2011.

Ghabang Sharab. "Gharban sharawyn zokhioson tod üsgiǐn dörwön oľradyn tüükh." National Library of Mongolia, Ms. no. 1407/96. Abbreviated DOT.

Halkovic, Stephen A., Jr. The Mongols of the West. Bloomington: Research Institute for Inner Asian Studies, Indiana University, 1985.

Jamba/Shamba. Asragch nertiīn tü̈̈kh (asarayči neretü-yin teüke). Ulaanbaatar: Bolor Sudar, 2011. Abbreviated $A N T$.

Junjichu manwen lufu zouzhe 軍機處滿文錄副奏摺. First Historical Archives of China, Beijing.

Kara, György. Books of the Mongolian Nomads: More than Eight Centuries of Writing Mongolian. Bloomington: Research Institute for Inner Asian Studies, Indiana University, 2005.

Khaltaryn Luwsanbaldan. Tod üseg tü̈niü dursgaluud, nemj bayajuulsan khoyor dakh' khewlel. Ulaanbaatar: Admon, 2015.

"Kho örlögiīn tüükh.” In Ǒ̃rad mongolyn tü̈̈khend kholbogdokh surwalj bichigüüd II, edited by Na. Sükhbaatar, pp. 155-166. Ulaanbaatar: Soyombo printing, 2001. Abbreviated KOT/Sükhbaatar.

Khodarkovsky, Michael. Where Two Worlds Met: The Russian State and the Kalmyk Nomads, 1600-1771. Ithaca: Cornell University Press, 1992.

Mongol ulsyn ikh surguul' ekh bichig altă sudlalyn tenkhim, translator and editor. Dă̌chin gürnǐ̆ 
dotood yaamny mongol bichgiun geriīn dans. Ulaanbaatar: Soyombo printing, 2010. Abbreviated DDMD.

Mongolyn ug ekhiin tuuj. Edited by Na. Sükhbaatar and M. Ulaan. Bibliotheca Oiratica XXXVII. Ulaanbaatar: Tod nomyn gerel töw and Soyombo printing, 2014.

“Qo-örlüg-ün teüke.” In Mongyol kitad qarilčayuluysan todu üsüg-ün oyirad mongyol-un teüke-yin surbulji bičig-ü̈̈ 蒙汉对照托式文字卫拉特蒙古历史文献译编, edited by Lij̃ei, pp. 52-56. Ürümchi: Sinǰiyang-un arad-un keblel-ün qoriy-a, 2009. Abbreviated KOT/Lijei.

Qinding Xiyu tongwen zhi 欽定西域同文志 Hesei toktobuha wargi aiman $i$ hergen be emu obuha ejetun $i$ bithe. Tokyo: Toyo Bunko, 1964. Abbreviated XTZ.

Qing shilu 清實錄. Beijing: Zhonghua shuju, 1985-1987.

Radnaabadraa. Rawjam zaya bandidyn tuuj sarny gerel khemeekh orshiw. Edited by Kh. Byambajaw. Bibliotheca Oiratica XII. Ulaanbaatar: Tod nomyn gerel töw and Soyombo printing, 2009.

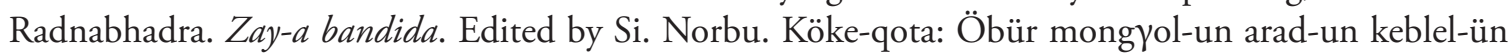
qoriy-a, 1999.

Radnabkhadra. Lunny̆ svet: Istoriia rabdzham Zaia-pandity. Translated by G. H. Rumiantseva and A. G. Sazykina. Saint Petersburg: Peterburgskoe Vostokovedenie, 1999.

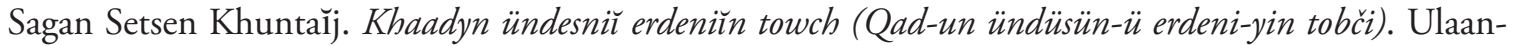
baatar: Bolor Sudar, 2011. Abbreviated ET.

Sperling, Elliot. "Pho-lha-nas, Khang-chen-nas, and the Last Era of Mongol Domination in Tibet." Rocznik Orientalistyczny 65.1 (2012): 195-211. 